\title{
Enforcement of Criminal Law against Criminal Acts of Online Business Fraud during the Covid-19 Pandemic in Indonesia
}

\author{
Ario Dewanto, Setiyono, and Supriyadi \\ Master of Legal Science Postgraduate Program \\ University Of Merdeka Malang \\ Indonesia
}

\begin{abstract}
Fraud cases dominated the crime rate over the internet during the Covid-19 pandemic. Many citizens who report instances of online fraud in purchasing goods dominate up to $25 \%$ of reports in the Police. This study used an empirical juridical approach and was analyzed using descriptive-analytical methods. In investigating online buying and selling fraud cases during the COVID19 pandemic, the Police experienced many obstacles and difficulties because issues related to cybercrime were handled differently from ordinary or conventional criminal cases. The strength of evidence is beneficial for investigators in investigating criminal cases because, without evidence, an issue cannot be resolved briefly. The crime of online business-based fraud during the Covid-19 pandemic is in principle the same as conventional fraud, but the difference lies in the evidence or means of action, namely using electronic systems (computers, internet, and telecommunication devices).
\end{abstract}

Key words: Business Fraud, Internet, Law Enforcement.

\section{INTRODUCTION}

The rapid development in information technology impacts the complex human need for the information itself. The internet has presented a new reality in life for every human being; the internet has also changed the system of distance and time to be unlimited. The internet can do a business transaction, study, shop, chat with colleagues worldwide, and even do activities others in real life. The relationship between information and communication network technology has resulted in a vast virtual world. This technology contains a collection of information accessed by everyone in the form of computer networks called the internet network as a service medium or information provider [1]. Internet technology has created a new society called a networked society that performs virtual social interactions, such as social interaction without media. Basically, in virtual interactions, several individuals or individuals deviate, one of which is committing fraud in social media [2].

An online business can make it easier for fraudsters, especially during the current covid 19 pandemic, where interaction between individuals is limited. The fraudulent mode of selling via the internet is by claiming a low price in the market so that many people are interested in buying it. Although some online business scams have been exposed, the prosecution of unscrupulous personstoMany of these actions has not been completed. This is because victims of online fraud are reluctant to report to law enforcement, while criminal acts of fraud are categorized as ordinary offenses [3]. Since the Covid-19 pandemic, around $40 \%$ of case reports have been received by the Police. Cases of fraud dominated the crime rate during the Covid-19 pandemic. Many citizens who report online fraud cases in purchasing goods dominate up to $25 \%$ of reports in the Police. The rest are cases of other crimes, such as theft/robbery and other crimes [4].

The covid-19 virus is a virus that attacks the human body through the consumption of food derived from wild animals such as rats, bats, and primates. The COVID-19 virus can attack the human body and cause death. During the COVID-19 pandemic, everyone is advised to avoid crowd mass which can accelerate the transmission of the covid 19 virus. People who like to shop in droves shop online because online shopping can minimize crowds of resident [5].

The law is the entire code of conduct that applies in life. Implementing the law can take place formally and peacefully, but it can also occur because violations of the law must be enforced ${ }^{[6]}$. Law enforcement that is not firm and clear against perpetrators of online business fraud is often a trigger for criminal acts of fraud, where according to the Criminal Law Act and Law Number 11 of 
2008 concerning information and electronic transactions as amended the last by Law Number 19 of 2016 concerning information and electronic transactions provides legal sanctions against the perpetrators of the fraudulent crime.

The case can be enforced by using two articles, namely as follows. Article 378 of the Criminal Code: "Whoever to benefit himself or another person by violating the law, by using a false name or false dignity, by deceit or by a series of lies moves another person to hand over something to him, or to give a debt or write off a debt, is threatened with fraud with a maximum imprisonment of 4 years." Article 28 paragraph (1) of Law Number 11 of 2008 concerning electronic information and transactions as amended by Law Number 19 of 2016 concerning electronic communication and commerce: "Everyone intentionally and without rights spreads news lie and misleading, resulting in consumer losses in electronic transactions."

The internet makes it easy for buyers to directly see the goods traded in cyberspace, pay for them by bank transfer, and only wait a few moments for the goods to arrive. The process of buying and selling through the internet is no stranger because the internet is not only for consumption by certain groups as in previous years but has penetrated the lower middle class of society. The buying and selling process through the internet, commonly called e-commerce or electronic commerce, is part of electronic business (electronic business) [7].

E-commerce is a trade transaction contact between sellers and buyers using internet media, where orders delivered to payment systems are communicated via the internet. The existence of e-commerce is a promising business alternative to be implemented today because e-commerce provides many conveniences for both parties, namely the seller (merchant) and the buyer (buyer), in conducting trade transactions even though the parties are located. In two different continents. Every transaction made by the two parties involved (seller and buyer) also does not require a face-to-face meeting or negotiation [8].

Cybercrime is a form of crime that arises due to internet technology. The rapid development in internet services invites corruption; with the increasing number of requests for internet access, crimes against users of information technology are increasing following the development of the technology itself. More and more parties are harmed by the perpetrators' actions of cybercrimes if there is no availability of laws that regulate it. Before enacting the Electronic Information and Transactions Law, law enforcement officers used the Criminal Code in dealing with cybercrime cases [9]. Initial data on online business criminal cases handled by Soekarno Hatta Airport is fraudulent buying and selling of online masks offered at low prices on social media. The mode is when the victim and the perpetrator agree on the amount of the mask price to be paid; then the perpetrator asks the victim to transfer the down payments as significant as $50 \%$ as collateral. In contrast, the rest will be paid when the victim receives the mask; after the down payment paid to the perpetrator made an appointment to hand over the masks at one of the places, the perpetrator never came, which resulted in the victim making a police report. This proves that the rapid development of science and technology is always followed or accompanied by the development of increasingly sophisticated and advanced crimes or criminal acts. Therefore, it is necessary to know more about the criminal act of online business fraud during the COVID-19 pandemic and the regulations used for this effort countermeasures by law enforcement officials. The introduction above can bed Problems 1) How is the enforcement of criminal law against online business fraud during the COVID-19 pandemic? 2) What are the inhibiting factors for criminal law enforcement against online business fraud during the COVID-19 pandemic according to positive law?

\section{RESEARCH METHODOLOGY}

The type of approach used is an empirical juridical approach. Empirical legal research is legal research that examines legal data in the field, such as legal data in its application, legal phenomena in society, problems of efficacy and effectiveness law, law enforcement and application, legal compliance, litigation issues, and dispute resolution, and so on [10]. The empirical approach is carried out by studying certain legal aspects that have practical value to answer questions and hypotheses that have been compiled coherently by examining field data through observation. The object of research on online-based fraud is the evidence or means of the act, namely using electronic systems (computers, internet, and telecommunication devices).

The type of data that the author uses in this study is divided into primary data and secondary data. Primary data is data obtained directly from the source person. This type of primary data is combined with legal materials that the authors get in the field so that the research results are balanced, accountable, and applied. Secondary data in this study include primary legal materials, secondary legal materials, and tertiary legal materials. Tertiary legal materials are legal materials that provide additional explanation or support for existing data on primary and secondary legal materials.

The data collection method in this study is to gather lawn and regulations or court decisions relating to the matters mentioned above. However, more essential is the search for legal books because there are many legal concepts. In addition, the author also uses the method of data collection by interview. The interview was conducted in-depth. Interviews were conducted with police station Malang Regency. 
The data obtained from the research results are then classified. After that, the writer analyzed using the descriptive method, namely using legal interpretation, legal reasoning, and rational argumentation. Then the author presents the data in narrative form to become clear and understandable sentences [11]. With this description as a basis, the authors draw conclusions that are also the answers to the main problems posed in the study.

\section{RESULTS FINDINGS}

\subsection{2 Criminal Law Enforcement Against Online Business Fraud During the Covid 19 Pandemic}

\section{Investigation Process}

The investigation carried out by the Police into the criminal act of online buying and selling fraud during the COVID-19 pandemic was carried out by the Malang Police for Certain Crime Units. According to Kusbiantoro, S.Sos, SH, MH, in investigating cases of online buying and selling fraud during the COVID-19 pandemic, the Police experienced many obstacles and difficulties because issues related to cybercrime were handled differently from ordinary or conventional criminal cases. Moreover, the perpetrators of these crimes can carry out their actions without the knowledge of others by using fake accounts. The agreement made between the seller and the buyer is also based on trust and does not meet in person, so it is easy for fraud perpetrators to carry out their actions. The steps taken by the Police are to conduct inspections, for example, at internet cafes which criminals usually use, as well as collect evidence, track and confiscate electronic proof such as hard disks, make disclosures, or detentions based on preliminary evidence or sufficient evidence - conducting investigations against criminals as described in the example of online buying and selling fraud cases during the covid 19 pandemic. The victims of the complainant said that the products offered on social media accounts such as Tokopedia, Bukalapak, and Lazada. The sale of these goods is diverse, including motorcycles, watches, agate, bicycles, cars, and various cell phones. At the same time, collect evidence, track, and confiscate electronic proof such as hard disks, make disclosures or detentions based on preliminary evidence or sufficient evidence. They were conducting investigations against criminals as described in the example of online buying and selling fraud cases during the covid 19 pandemic. The victims of the complainant said that the products offered on social media accounts such as Tokopedia, Bukalapak, and Lazada. The sale of these goods is diverse, including motorcycles, watches, agate, bicycles, cars, and various types of cell phones. At the same time, collect evidence, track, and confiscate electronic proof such as hard disks, make disclosures or detentions based on preliminary evidence or sufficient evidence. They were conducting investigations against criminals as described in the example of online buying and selling fraud cases during the covid 19 pandemic. The victims of the complainant said that the products offered on social media accounts such as Tokopedia, Bukalapak, and Lazada. The sale of these goods is diverse, including motorcycles, watches, agate, bicycles, cars, and various cell phones. They were conducting investigations against criminals as described in the example of online buying and selling fraud cases during the covid 19 pandemic. The victims of the complainant said that the products offered on social media accounts such as Tokopedia, Bukalapak, and Lazada. The sale of these goods is diverse, including motorcycles, watches, agate, bicycles, cars, and various types of cell phones. They were conducting investigations against criminals as described in the example of online buying and selling fraud cases during the covid 19 pandemic. The victims of the complainant said that the products offered on social media accounts such as Tokopedia, Bukalapak, and Lazada. The sale of these goods is diverse, including motorcycles, watches, agate, bicycles, cars, and various types of cell phones.

Based on the results of interviews with Kusbiantoro, S.Sos, SH, MH, as well as the effects of observations, it is stated that a defendant can be prosecuted before the District Court on the condition that 1) there is an error on the Defendant either in the form of intentional or negligence, 2) the Defendant can be held accountable for his actions which means there is no excuse for forgiveness ex: Article 44 of the Criminal Code and justifying reasons Ex: Article 50 of the Criminal Code, 3) The Defendant's actions have fulfilled the formulation (article element) of a criminal act proven by at least 2 pieces of evidence as regulated in article 184 paragraph (1) of the Criminal Procedure Code.

Article 378 of the Criminal Code stipulates as follows "anyone with the intent to profitable yourself or others unlawfully by using a false name or false dignity, by deceit or a series of lies, inducing another person to hand over something to him, or to give a debt or write off a debt, is threatened with fraud, with a maximum imprisonment of four years. Article 28 paragraph (1) of Law no. 19 of 2016 concerning Information and Electronic Transactions stipulates as follows "everyone intentionally and without rights spreads false and misleading news that results in consumer losses in Electronic Transactions." According to the author, Enforcement efforts carried out by the Police in investigating criminal acts of online buying and selling fraud have encountered many obstacles where it is difficult to find the perpetrators because usually, the perpetrators use fake accounts and fake identities in making account numbers. So the Police should also urge the public to be more careful in conducting online buying and selling transactions. 
Investigation Process, Investigate the perpetrator and make a report on the results of the case file. According to Kusbiantoro, S.Sos, SH, MH, the research carried out by the Police did not recognize regional boundaries. Therefore it is necessary to cooperate with other law enforcement officers. Because this is very important to collect evidence, confiscation of electronic evidence of cybercrime perpetrators. An investigation conducted by the Police traced the source of the electronic document. In practice, usually, investigators will first track down the whereabouts of the perpetrator by tracing the Internet Protocol address "IP Address" of the perpetrator based on the information IP logs the address stored on the website/homepage manager server is used as a means for perpetrators to commit fraud. The problem is investigators encounter difficulties if the owner of the website/homepage is outside the jurisdiction of Indonesia (such as Facebook, Google, Twitter, Yahoo, etc.). Although currently, the Police and Civil Service Investigators of the Ministry of Communication and Information have collaborated with several website/homepage managers outside the territory of Indonesia, in practice, it is not easy to obtain the IP address of a perpetrator suspected of committing a crime by using certain web site/homepage services. This is due to differences in legal procedures between countries. Although inter-state governments, through their law enforcement officers, have made Mutual Legal agreement assistance or mutual legal assistance agreements, are in fact, Mutual Legal Assistance does not necessarily apply in every case involving between countries. This jurisdictional problem is often the cause of the non-processing and processing of cybercrime. In the investigation process, evidence is needed inside. Article 184 of the Criminal Procedure Code, valid evidence is witness testimony, expert testimony, letters, instructions, and statements from the Defendant [12].

Process of Evidence in Criminal Cases (Prosecution), The evidentiary system regulates the types of evidence that may be used, the description of the evidence and how the evidence is used, and how the judge must form his belief ${ }^{[13]}$. The sources of evidentiary law are laws, doctrines or teachings, and jurisprudence. This system or theory of proof varies according to time and place. In the following, the author will describe the four methods or approaches of evidence mentioned above as follows:

Positive proof system or theory based on the law (Positief Wettelijke Bewijs Theorie), it is positive because it is only based on the law. This means that if an act has been proven by the evidence referred to by law, then the judge's conviction is not needed at all. This system is also known as formal proof theory. This system focuses on the existence of valid evidence according to the law. Although the judge is not sure of Defendant's guilt, if there is good evidence according to the law, then he can impose a sentence on Defendant. So, for example, two witnesses have been sworn in and say that the Defendant is guilty, the judge must impose a criminal penalty on the Defendant even though the judge may believe that the Defendant is innocent.

System or theory of evidence based on the judge's conviction, this system or theory gives too much freedom to judges to be challenging to monitor. In this case, the law's Defendant or advisor is challenging to defend. According to this system, it is considered sufficient that the judge bases the proof of a situation on mere belief without being bound by a rule. In this system, judges can, according to very feelings, determine a condition that must be considered proven.

A system or theory of evidence based on the judge's belief on logical grounds (La Conviction Rais one), according to this theory, the judge can decide a person is guilty based on his belief based on evidence and a conclusion based on specific evidentiary rules. This system or approach of evidence is also called free evidence because the judge can state the reasons for his belief. This system gives judges too much freedom, making them difficult to monitor. In addition, the Defendant or advisor of the law is difficult to defend. In this case, the judge can convict the Defendant based on his belief that he has done what he is charged with.

The theory of evidence based on the law negatively (Negatief Wettelijk), Herzien Inlandsch Reglement, the Criminal Procedure Code, and the old and new Ned.Sv all adopts a system or theory of evidence based on the law negatively (negative wettelijk). This can be concluded from Article 183 of the Criminal Procedure Code, formerly Article 294 of the Herzien Inlandsch Reglement. The Article reads: "A judge may not impose a sentence on a person unless with at least two valid evidence he obtains the belief that a criminal act has occurred and that the defendant is guilty of committing it." From the provisions of Article 183 of the Criminal Procedure Code above, it is clear that evidence must be based on the Criminal Procedure Code, namely valid proof, accompanied by the judge's conviction obtained from the evidence. This right can be said to be the same as the provisions referred to in Article 294 paragraph (1) of the Herziene Inlands Regulation, which reads: No one may be subject to a crime, except if the judge is convinced with valid evidence that it has happened. Acts that can be punished are people who are found guilty.

Court process, law enforcers must be able to prove in various ways and with the evidence that has been set according to the act. Law enforcers are not allowed to leave the provisions that have been regulated in the law regarding the methods and conditions of evidence; if they leave the rules, the methods and evidence are invalid or inappropriate - shown in court. In procedural law, the judge's belief determines a decision in court. According to the theory of negative evidence of the law, the judge's decision must have complete confidence; without conviction, the judge must seek that belief by considering the facts revealed in court. 
The facts revealed in court must also have a strong basis; this basis is evidence shown in court. This evidence must also be obtained prearranged and set in the act. In addition to the proof system above, proof must also accompany assurance. This evidence will strengthen a claim for a criminal act committed by the perpetrator. The Criminal Procedure Code regulates limited evidence. At the same time, the evidentiary value of all evidence is based on an evaluation judge. Five pieces of evidence are recognized in the Criminal Procedure Code in Article 184, namely [14].

Witness Statement, the material requirements for witness testimony include, among other things, the information given is an event that he heard, saw, and experienced for himself based on his knowledge, not an opinion or fiction or expert testimony. Next, more than one witness agrees with the unus testis nullus testis principle. There is a match between the testimony of one witness to another and the testimony of a witness with other evidence. It is necessary to pay attention to several main provisions that must be fulfilled by a witness, namely the need to take an oath or promise, witness testimony which is valuable as evidence, witness testimony must be given in court, the testimony of one witness alone is considered insufficient and the testimony of several independent witnesses.

Expert Description, article 186, which meant expert testimony, is what an expert states in court. Article 184 paragraph 1 of the Criminal Procedure Code stipulates that specialist testimony is valid evidence. Expert description disinformation given by someone who has particular expertise on matters needed to make light of a criminal case for examination and must take an oath or promise before the court.

Letter of Evidence, according to the provisions, letters that can be assessed as valid evidence according to the law are made on an oath of office or a note confirmed by oath. Then the Article itself has extensively detailed the forms of messages that can be considered to have value as evidence:

Minutes and other notations in official form made by public officials who authorized or pushed in front of him; A letter in the form of a statutory provision or a note made by an official regarding matters included in the procedures for which he is responsible and intended to prove something or a situation; certificate from an expert containing an opinion based on his expertise regarding a matter or a situation that is officially requested from him; Another letter that can only be valid if it has something to do with the contents of other evidence

Hint Evidence Tool, Instructional evidence is a sign that can draw from an act, event, or situation where the signal is compatible with one another or the call is by the crime itself, and from the corresponding signal gives birth or creates an indication that forms the reality of the occurrence of a crime and the Defendant is the perpetrator. The Criminal Code regulates the source of instructions. Namely, education can only be obtained from witness statements, letters, and statements from Defendant. Based on the Criminal Procedure Code, the judge who can determine the guiding evidence is the judge who is carried out after examining the three pieces of evidence with great care and thoroughness based on his belief and research on instructions,

Defendant's Statement, defendant's statement as evidence, at the same time, includes the idea of confession and denial and the submission of his assessment to the judge, which of the Defendant's argument is an expression of confession which part of the statement contains denial. Provisions regarding evidence as regulated in the Criminal Procedure Code as described above meant that the evidence presented at trial is valid so that it can be used in the problem so that the elements of the crime are by the evidence submitted [14].

\subsection{Factors Inhibiting Criminal Law Enforcement Against Online Business Fraud during the Covid 19 Pandemic}

As has been stated, the basis of a prosecution for the prosecutor general must be based on valid evidence as stipulated in article 184 of the Criminal Procedure Code. Likewise, judges in deciding criminal cases must be based on Article 184 of the Criminal Procedure Code. The evidence outlined in Article 184 of the Criminal Procedure Code must be by the facts, meaning no fabrication. In article 184 of the Criminal Procedure Code, valid evidence is witness testimony, expert testimony, instructions, and Defendant's statements [12].

However, some witnesses currently give false statements, perhaps because they are close to Defendant. Sometimes the judge immediately believes in the testimony presented by the witness at trial. Although the evidence is valid, there are still many false pieces of evidence, for example, false statements from a witness, letters, or other evidence that are not by the existing facts. In other words, a witness may say things that are not true to Defendant even though he has been sworn in. A defendant is indeed guilty, but with the information was given by the witness, the sentence for Defendant may be commuted; understandably, the evidence is seen from a criminal legal perspective; It is challenging to find anonymous accounts (fake accounts that are difficult to detect); for example, perpetrators use counterfeit versions such as emails used as websites to sell counterfeit or fictitious goods that can attract the attention of people who want to shop online media; Personal data or electronic media belong to the perpetrator, such as discarded electronics cellphone numbers that are no longer active. After the perpetrator finds the victim, using a cellphone 
and card that is not permanent or used temporarily can make it difficult for the Police to track down the whereabouts of the perpetrator.

\section{CONCLUSIONS}

The crime of online business-based fraud during the Covid-19 pandemic is in principle the same as conventional fraud, but the difference lies in the evidence or means of action, namely using electronic systems (computers, internet, and telecommunication devices). The enforcement of criminal law against perpetrators of online business fraud is carried out by the rules of criminal law, namely the criminal law code, because in cases where there is an element of fraud subject to article 378 of the criminal law code where law enforcement starts from several stages. But because in Article 378 of the Criminal Code the criminal threat is too light, the police apparatus uses Article 28 paragraph (1) and Article 45A paragraph (1) of Law Number 19 of 2016 concerning information and electronic transactions; it can also be subject to Article the. In this case of online business fraud, the process is carried out by the Police to investigate whether a fraud event has occurred, and then it is examined by way of processing the crime scene by the Police.

The inhibiting factor for criminal law enforcement against online business fraud during the COVID-19 pandemic is the legal factor itself, where there are still rules that do not specifically explain criminal acts. Fraud based online business fraud. Then it is challenging to find anonymous accounts (fake accounts that are difficult to detect); for example, perpetrators use counterfeit versions such as emails used as websites to sell fake or fictitious goods that can attract people's attention who want to shop online media. In addition, personal data or electronic media belonging to the perpetrator, such as discarded electronics cellphone numbers that are no longer active. After the perpetrator finds the victim, using a cellphone and card that is not permanent or is used temporarily can make it difficult for the Police to track down the perpetrator's whereabouts.

\section{SUGGESTION}

The Indonesian government, through related institutions, should be able to include law enforcement officers in education and training activities specifically to improve the quality and ability of law enforcement officers in uncovering cases of online business fraud and providing facilities and infrastructure by the specifications expected to be able to find and arrest criminals.

\section{REFERENCES}

1. Bakri, A. A. A. The Impact of Social Media Adoption on Competitive Advantage in the Small and Medium Enterprises. International Journal of Business Innovation and Research, Vol.13, No.2, 2017

2. Busroh, F. F., \& Haryadi, T. 2021. Normative Analysis of Fraud Prevention Efforts Through Internet Media (Internet Freud) in the Perspective of International Law and Its Constraints. The Academic Community of the College of Law, the Youth Pledge.

3. Kirwan, G. H., Fullwood, C., \& Rooney, B. 2018. Risk Factors for Social Networking Site Scam Victimization Among Malaysian Students. Cyberpsychology, Behavior, and Social Networking, Vol.21, No.2.

4. Zulkifli, N. F. R. 2021. Legal Protection Against Victims of Online Buying and Selling Fraud During the Covid-19 Pandemic at Polrestabes Surabaya. Journal of Syntax Transformation, Vol.2, No.5.

5. Sun, P., Lu, X., Xu, C., Sun, W., \& Pan, B. 2020. Understanding of Covid-19 Based on Current Evidence. Journal of Medical Virology, Vol.92, N0.6.

6. Harefa, S. 2019. Law Enforcement Against Criminal Acts in Indonesia Through Positive Criminal Law and Islamic Criminal Law. University Of Bengkulu Law Journal, Vol.4, No.1.

7. Carta, S., Fenu, G., Recupero, D. R., \& Saia, R. 2019. Fraud Detection for E-commerce Transactions by Employing a Prudential Multiple Consensus Model. Journal of Information Security and Applications, Vol.46,

8. Zhang, M., Yao, Y., Jiang, Y., Li, B., \& Tang, C. 2018. Accountable Mobile E-Commerce Scheme in Intelligent Cloud System Transactions. Journal of Ambient Intelligence and Humanized Computing, Vol.9, No.6.

9. Setiawan, N., Tarigan, V. C. E., Sari, P. B., Rossanty, Y., Nasution, M. D. T. P., \& Siregar, I. 2018. Impact of Cybercrime in EBusiness and Trust. int. J. Civ. eng. Technol, Vol.9, No.7.

10. Fuady, M. 2018. Legal Research Methods Theory and Concept Approach. King Grafindo Persada. Depok

11. Yusuf, M. 2014. Research Methods; Quantitative, Qualitative, and Combined Research. Prenada Media. Jakarta

12. Hamzah, A. 2011. KUHP \& KUHAP 17th Edition. Jakarta: Rineka Cipta.

13. Sasangka, H., and Rosita, L. 2003. Law of Evidence in Criminal Cases. Forward Mandar. Bandung.

14. Sitompul, J. 2012. Cyberspace Cybercrime Cyberlaw Overview of Criminal Law Aspects. Tatanusa. Jakarta 